\title{
DOMESTIC VIOLENCE COURT: A NEW MODEL TO COMBAT DOMESTIC VIOLENCE AGAINST WOMEN IN MALAYSIA
}

\author{
Nazli Mahdzir,* Senior Lecturer, School of Law, UUM COLGIS, \\ Universiti Utara Malaysia, Malaysia. \\ E-mail: mnazli@uum.edu.my
}
Aspalella A Rahman, Senior Lecturer, School of Law, UUM COLGIS, Universiti Utara Malaysia, Malaysia. E-mail: lella@uum.edu.my

Asmar Abd Rahim, Senior Lecturer, School of Law, UUM COLGIS, Universiti Utara Malaysia, Malaysia. E-mail: asmar@uum.edu.my

Che Thalbi Ismail, Senior Lecturer, School of Law, UUM COLGIS, Universiti Utara Malaysia, Malaysia. E-mail: chet1048@uum.edu.my

\begin{abstract}
Domestic violence is a social epidemic in Malaysia. To combat this, the Domestic Violence Act 1994 and the Domestic Violence (Amendment) Act 2012 has set up a mechanism via the Malaysian criminal justice system to investigate reports, prosecute the perpetrators and protect the victims of domestic violence. Unfortunately, the mechanism has been viewed with disfavor by many. This paper attempts to critically appraise the effectiveness of the mechanism and subsequently propose an alternative method to better deal with domestic violence cases. Applying a descriptive and analytical approach in data analysis, the paper concluded that the mechanism currently being implemented in dealing with domestic violence cases is ineffective and ineffectual. Therefore a specialized court (instead of the current criminal court) which deals specifically with domestic violence is suggested.
\end{abstract}

Keywords: Domestic violence; women; domestic violence court 


\section{INTRODUCTION}

January 2014: a man slashes his wife's face after she defied his order not to visit her mother. February 2014: a woman dies after she was believed to be slashed by her husband after an argument. March 2014: a man beat and set his wife on fire because he suspected her of having an affair. April 2014: a woman died after being savagely beaten by her husband. ${ }^{1}$

Domestic violence against women in Malaysia has evolved from what was once considered as private family matter to a social epidemic. $39 \%$ of Malaysian women above 15 years of age were estimated to have been physically beaten by their partner. ${ }^{2}$ According to statistics released by the Ministry of Women, Family and Community Development, the number of reported cases of domestic violence against women is on a steady climb.

\begin{tabular}{lcc}
\hline Year & Total Reported Cases & Cases involving Women as Victim \\
\hline 2010 & 3173 & 2522 \\
2011 & 3277 & 2477 \\
2012 & 3288 & 2558 \\
\hline
\end{tabular}

(Bernama: 2013).

Whilst the Government of Malaysia fully committed to curtailing domestic violence via various legislative, public health and enforcement measures, the discord between policy and practice lead to imbalance between the number of cases reported and the number of cases brought to court (Australian Government: 2012). While reported cases are increasing, the number of cases brought to court sadly not as much. Attitude and low level of knowledge of women about their rights in law are among the key factors to this problem. Many are ashamed or afraid to bring the case to court for

\footnotetext{
S. Indramalar (2014). Refuse Abuse: Finding the Power to Stop Domestic Violence, The Star Online, 25th April 2014, http://www.thestar.com.my/ Lifestyle/Features/2014/04/25/Refuse-abuse-Finding-the-power-to-stopdomestic-violence/

2 Sajaratulnisah Othman (2008). Domestic Violence Management in Malaysia: A Survey on the Primary Health Care Providers, Asia Pacific Family Medicine, $7: 2$
} 
domestic violence is considered purely domestic problem that need to be hidden. The ineffectiveness of the current legal mechanism in dealing with a type crime which is sensitive in nature and requires special attention also contributes to the problem. Therefore it is high time the Malaysian government revisits the law on domestic violence and establishes a special court to resolve cases of domestic violence more efficiently.

\section{PROBLEM WITH THE CURRENT SYSTEM DEALING WITH DOMESTIC VIOLENCE PROSECUTION IN MALAYSIA}

Domestic violence against women is as any behavior which results in physical, sexual and/or psychological damage, forced social isolation, economic deprivation or behavior which leaves a woman in fear. ${ }^{3}$ It may include sexual abuse, forced imprisonment, destruction of property, emotional and psychological abuse, harassment or threat thereof. The actions are often done through the exercise of force, destructive verbal communication or emotional harassment by another member of the household.

As signatories to the United Nations Convention on the Elimination of All Forms of Discrimination against Women (CEDAW), legislation, activities and community based program relating to domestic violence against women has been given priority by various governmental agencies ${ }^{4}$ such as the Ministry of Women, Family and Community Development as well NGOs such as Women's Aid Organization, All Women's Action Society Malaysia and Join Action Group for Gender Equality. Malaysia is the first country in the Asia Pacific Region which introduces specific Act to address domestic violence.

Nor Aini Abdullah (1995). Marital Rape - Domestic Violence, Malayan Law Journal Article, 2 MLJ lvii, lvii-lxvi

4 Hussein Haniff (2013). Statement by Permanent Representative of Malaysia to the United Nations on Agenda Item 3: Follow-up to the Fourth World Conference on Women and to the Twenty-Third Special Session of the General Assembly, United Nation Fifty-Seven Session of the Commission on the Status of Women, 11 March 2013, http://www.un.org/womenwatch/daw/csw/csw57/ generaldiscussion/memberstates/malaysia.pdf 
The Domestic Violence Act 1994 (Act 521) ${ }^{5}$ was introduced in 1994 and implemented two years later. The Act was then amended by the Domestic Violence (Amendment) Act 2012 (Act A1414). The purpose of DVA is to provide legal protection in situations of domestic violence and matters incidental thereto. The Act recognizes all forms of domestic violence as sizeable offences, ${ }^{6}$ guarantees protection for the victims ${ }^{7}$ and provides suitable support for them. ${ }^{8}$ Under the DVA, domestic violence against women can take the form of any act which causes physical injury or placing the survivor in fear of physical injury; compelling the survivor by force or by threat to engage in any conduct, sexual or otherwise; destruction or damage of property; confining or detaining the survivor against her will; physical and psychological abuse such as put-downs and insults ${ }^{9}$ perpetrated against women by their spouse, former spouse or family members. ${ }^{10}$

Unfortunately, although the DVA is design to provide legal protection in situations of domestic violence and matters incidental thereto, the Act does not recognize domestic violence as crime per se. ${ }^{11}$ Domestic violence is not defined as a specific crime punishable by new penalties, but it is attached to the Penal Code (Act 574) other written law involving offences ${ }^{12}$ relating to domestic violence under definitions and procedures for hurt, threat, criminal force and assault. The process and procedures of investigation is determined by the Criminal Procedure Code. ${ }^{13}$ Since domestic violence is deemed as crime against person under the Penal Code, the cases are heard by ordinary courts and subject to the same procedures as other criminal cases. ${ }^{14}$

\footnotetext{
Hereinafter referred to as the DVA.

Section 18A of the DVA.

Sections 4, 5,6,7,8,9,12,12A,12B,13,14,15,16,17 and 17A of the DVA.

Sections 10 and 11 of the DVA.

Section 2 of the DVA.

10 All Women's Action Society Malaysia (2009), http://www.awam.org.my/ domesticv.html

11 Ching Mey See and Cecilia A. Essau (2012). Overview of Violence and Abuse in Malaysia. In Angela Browne-Miller (Ed.), Violence and Abuse in Society: Understanding the Global Crisis, 251-264, California: ABF-CLIO,LLC

12 Section 3 of the DVA.

13 FMS (cap 6).

14 Abdulfatai O. Sambo and Abdulkadir B. Abdulkadir (2012). "Legal Approach To Domestic Violence In Malaysia And Nigeria: An Expository Study Of The Experience In Selected Jurisdictions" [2012] 1 LNS(A) XV
} 
The current court system used for criminal cases is less suitable for use in cases of domestic violence. ${ }^{15}$ The system lack the understanding of the complexities of domestic violence especially the powerful social, emotional and economic ties that bind victims to their abusers. It also lacks gender sensitivity as well as sense of security and protection which are crucial in domestic violence cases. However the most glaring disadvantage of our judicial system with respect to domestic violence is the fact it requires an extensive knowledge on Family Law (both laws governing Muslim and NonMuslims) as well as Criminal Law on the part of the judge, lawyers as well as the court officers. Since Malaysia have no comprehensive single code to deal with all Family Law matters, ${ }^{16}$ the administration of family law is not administered as a consistent whole. Different matters have to be brought to different courts albeit being interrelated. ${ }^{17}$ For example a petition for divorce by a Non-Muslim is heard by the High Court. However, if the parties are also bringing actions for maintenance, custody, division of matrimonial properties as well as domestic violence, the Magistrate, Session and High Court can exercise jurisdiction over the actions. The Muslims also faces the same problem, While the Syariah Court have jurisdiction to hear petition for divorce, distribution of matrimonial properties, maintenances and guardianship, domestic violence cases must be brought to the Civil Court. Thus, requiring the victim to go to two different jurisdictions of courts. ${ }^{18}$

\section{THE POSSIBILITY OF INTRODUCING DOMESTIC VIOLENCE COURT}

It is submitted that the introduction of Domestic Violence Court is the most effective measure to be taken in solving problems

\footnotetext{
15 Abu Bakar Munir and Nor Aini Abdullah (1995). "Domestic Violence and the Need for a Family Court", 4 Current Law Journal ixxv (Nov)

16 Apart from the DVA, provisions relating to family matters can be found in Law Reform (Marriage and Divorce) Act 1976 (Act 164), Adoption Act, Guardianship of Infants Act, Legitimacy Act, Distribution Act, Inheritance (Family Provision) Act, Child Act 2001 (Act 611), Administration of Family Laws Enactments as well as Administration of the Syariah Enactments in the various states each states.

17 Ibid.

18 Ibid.
} 
relating to domestic violence prosecution. It will be a 'One-Stop Centre' to deal with domestic violence prosecution as well as all matters incidental thereto such as application for Protection Order and Interim Protection Order, power of arrest, application for compensation for injuries and financial losses ${ }^{19}$ and application for referral to conciliatory body. ${ }^{20}$

The biggest challenge in establishing a Domestic Violence Court is the unique nature of domestic violence which involved not only criminal behaviour but complex social relationships. Unlike victims of crime committed by strangers (non-family related persons), women in domestic violence cases often have multiple reservations about co-operating with legal process such as fear, economic dependence, affection and shame. ${ }^{21}$ Therefore the establishment of Domestic Violence Court must take into consideration the following:

a. Specialized Staff - similar to other 'problem solving courts' such as Interlectual Property Court and Juvenile Court, the Domestic violence court must be equipted with specially trained court staffs and non-court professionals. Apart from judges and court officers who are trained in family and crimial law, victims advocates who understood the emotional and material needs of victims and who could work with them during the life of a case must be placed at the court.

b. Permanent Judge for Specific Case - Assigning a single permanent judge to handle domestic violence cases throughout the proceeding helps to ensure consistency, quick disposal of case (the judge is well verse with the case) and also help the judge to be well-versed in responding to the special issues presented by domestic violence thus enable him to make a more informed decisions. ${ }^{22}$

\footnotetext{
Section 10 of the DVA.
}

Section 11 of the DVA.

21 Wolf, Robert V. and Aldrich, Liberty, et. al (2004). Planning a Domestic Violence Court The New York State Experience, Center for Court Innovation, http://www.courtinnovation.org/research/planning-domestic-violence-courtnew-york-state-experience

22 Robyn Mazur and Liberty Aldrich (2003). "What Makes a Domestic Violence Court Work? Lessons from New York", American Bar Association Number 2 Volume 42, Spring 2003. 
c. Safety - the setting of a Domestic Court must be able to provide a sense of safety to the victim. Similar to other assault victims, all victims of domestic violence have the fear of going to court to face their assailant. This feeling is accelerated in cases of domestic violence since the victims are normally economically dependant on the assailant. They may also be treatned by the assailant or their family during the course of the proceeding. Therefore, the Domestic Violence court must be set up with facilities to enable the victim to testify or to observe the proceeding without having to be in the court physically. The court also must include private space to for the victim to confer with their lawyers and separate waiting areas equipt with victim services / advicates. ${ }^{23}$

d. Immediate access to Legal Counsel and Victim Advocate Service - every victim must be given immediate access to legal counsel who can advise them the court procedures as well as victim advocate who can provide safety planning, access to counseling and other services to ensure victim can be self-sufficient through out the court process and after the trial ended.

e. Immediacy - the court process must one which allows the assilant to be brought to trial in the shortest of time. This will enable the court to respond more quickly and efficiently to violations, prevent problems form escalating and also send a message to the assailant that the court was taking the charges against them seriously. ${ }^{24}$

f. Intensive Monitoring - the court must establish network with the law enforcement agency and other court room players to conduct rigorous monitoring of assailants and victims. This can assist the court enforce orders of protection and keep victims safe.

g. Effective Communication - Network or linkages between the court, law enforcement agency and other court room players must be establish so that information such as violation of 
protection order can be communicated and action can be taken swiftly

h. Keep victims informed - the victims must be keep up to date with the latest information regarding their cases. This reduces the burden on the victim to constantly reappear in court to find out the status of her case, reduces the changes of the victim having to come face to face with her assilant, and provide a sense of confort to the victim; that the system cares about her welfare $^{25}$

Model of Domestic Violence Court can be seen from established family courts in some countries such as Australia and the United States of America. In Australia, cases of domestic violence cases are heard by the Family Court of Australia. ${ }^{26}$ The main objective of this court is to address the problem of family law through judicial and non-judicial process. The proceedings follow the Family Violence Best Practice Principles ${ }^{27}$ established by the Family Court of Australia and the Federal Circuit Court of Australia through the Family Violence Committee. In the state of New York, America, state court system has developed Domestic Violence Court, an integrated court where the presiding judge handle all issues (both criminal and civil) affecting domestic violence. The court featured a single presiding judge, a fixed prosecutorial team, and enhanced staffing to monitor defendant compliance and provide assistance to victims. The integrated court also allows multijurisdictional matters to be heard by a single court. Therefore matters incidental to domestic violence prosecution such as Protection Orders, custody of children during proceeding and visitation to be heard by the same court.

Studies conducted by several practitioners, victim advocates and researchers in the United States of America has shown that the setting up of Domestic Violence Court contributes to enhanced coordination

\footnotetext{
25 Ibid.

26 The Family Law Courts in Australia is divided into two parts; Family Court of Australia and the Federal Circuit Court of Australia. Each has a different jurisdiction.

27 Federal Circuit Court of Australia (2012). Family Violence Best Practice Principles - April 2013, http://www.federalcircuitcourt.gov.au/wps/wcm/ connect/fccweb/reports-and-publications/publications/family-law/familyviolence-best-practice-principles-april-2013
} 
of cases, more consistent procedures, treatment of litigants, rulings and orders, speedy and comprehensive relief for victims at an earlier stage of the judicial process. It also enable the proceeding to be more victim-centered, provide greater understanding on the complexity of the cases, promote better compliance with orders among assailant and finally give greater confidence on the part of the community, that the justice system is responding as well as greater system accountability. ${ }^{28}$

\section{CONCLUSION}

For the domestic violence against to be reduced, it is essential that the realities of domestic violence be understood. The legislature and the judicial system must cater to the complex needs of battered women. The unique and progressive nature of domestic violence demands innovation from the entire criminal justice system. Experience in the state of New York for example shows that domestic violence courts have been able to change the way that the criminal justice system approaches domestic violence cases. Therefore it is believed that the establishment of Domestic Violence Court is in line with the current trend towards a comprehensive approach to problem of domestic violence, simplify the court process for women in distress, create an environment where victims no longer have to navigate multiple court systems and at the end of the day give the victims the protection they sorely needed.

\section{BIBLIOGRAPHY}

S. Indramalar. (2014). Refuse Abuse: Finding the Power to Stop Domestic Violence, The Star Online, $25^{\text {th }}$ April 2014, http:// www.thestar.com.my/Lifestyle/Features/2014/04/25/Refuseabuse-Finding-the-power-to-stop-domestic-violence/

Sajaratulnisah Othman. (2008). Domestic Violence Management in Malaysia: A Survey on the Primary Health Care Providers, Asia Pacific Family Medicine, 7:2.

Susan Keilitz (2004). Specialization of Domestic Violence Case Management in the Courts: A National Survey, NCJRS: Rockville USA 
Bernama. (2013). Domestic Violence on the Rise Since 2010, Borneo Post Online, 13 ${ }^{\text {th }}$ October 2013, http://www.theborneopost. com/2013/10/13/domestic-violence-on-the-rise-since-2010/

Nor Aini Abdullah. (1995). Marital Rape - Domestic Violence, Malayan Law Journal Article, 2 MLJ lvii, lvii-lxvi

Ching Mey See \& Cecilia A. Essau. (2012). Overview of Violence and Abuse in Malaysia. In Angela Browne-Miller (Ed.), Violence and Abuse in Society: Understanding the Global Crisis, 251-264, California: ABF-CLIO,LLC.

Nor Azilah Hj Jonit. (2006). Country Report - Malaysia, United Nations Asia and Far East Institute for the Prevention of Crime and the Treatment of Offenders (UNAFEI), http:// www.unafei.or.jp/english/pages/RMS/No69.htm

Australian Government. (2012). Country Advice Malaysia, 1. What are the attitudes towards domestic violence (DV) by the Government of Malaysia? 2. What (if any) women's refuges exist for victims of $D V$ ? 3. What assistance might a woman expect from police with respect to death threats by her husband and son?, Australia: Refugee Review Tribunal, http://www.refworld.org/docid/5146fa4b2.html

All Women's Action Society Malaysia. (2009). http://www.awam. org.my/domesticv.html

Abdulfatai O. Sambo Abdulkadir B. Abdulkadir (2012). "Legal Approach To Domestic Violence In Malaysia And Nigeria: An Expository Study Of The Experience In Selected Jurisdictions" [2012] 1 LNS(A) xv

Federal Circuit Court of Australia. (2012). http://www.family lawcourts.gov.au

Federal Circuit Court of Australia. (2012). Family Violence Best Practice Principles - April 2013, http://www. federalcircuitcourt.gov.au/wps/wcm/connect/fccweb/reportsand-publications/publications/family-law/family-violencebest-practice-principles-april-2013

Abu Bakar Munir, \& Nor Aini Abdullah (1995). "Domestic Violence and the Need for a Family Court", 4 Current Law Journal ixxv (Nov).

Robyn Mazur \& Liberty Aldrich. (2003). "What Makes a Domestic Violence Court Work? Lessons from New York", American Bar Association Number 2 Volume 42, Spring 2003. 
Susan Keilitz. (2004). Specialization of Domestic Violence Case Management in the Courts: A National Survey, (NCJRS: Rockville USA)

Wolf, Robert V., \& Aldrich, Liberty Aldrich et. al. (2004). Planning a Domestic Violence Court The New York State Experience, Center for Court Innovation, http://www.courtinnovation.org/ research/planning-domestic-violence-court-new-york-stateexperience

Ong Chin Lan. Local Government Partnering With The Community in Preventing Violence Against Women: Scenario of Violence Against Women in Malaysia and the Initiatives of Royal Malaysia Police in Helping Victims of Crime, Sexual, Women \& Child Investigation Division (D11), Criminal Investigation Department, Bukit Aman, http://wyf.org.my/images/vaw/Files/ k\%20Paper\%20Presentation $\% 20 \% 20$ Scenario\%20of\%20 Violence\%20Against\%20Women\%20in\%20Malaysia.pdf

Hussein Haniff. (2013). Statement by Permanent Representative of Malaysia to the United Nations on Agenda Item 3: Follow-up to the Fourth World Conference on Women and to the TwentyThird Special Session of the General Assembly, United Nation Fifty-Seven Session of the Commission on the Status of Women, 11 March 2013, http://www.un.org/womenwatch/ daw/csw/csw57/generaldiscussion/memberstates/malaysia. pdf 